\title{
Pengaruh PSAK 108, Produk Unit Linked terhadap Asumsi Going Concern Perusahaan Asuransi Syariah di Indonesia
}

\author{
Nano Suyatna \\ Fakultas Komputer, Universitas Ma'soem \\ Email korespondensi: nanosuyatna@masoemuniversity.ac.id
}

\begin{abstract}
It is recommended that tomorrow's risk is anticipated in Islam, the applicant can use Sharia Life Insurance. The problem is the emergence of insurance companies that fail to pay, so that customer expectations are lost. This study aims to provide input in choosing the right insurance company and add insight for those interested in insurance. The research method used is descriptive quantitative research methods. The results showed that: $a$. the positive influence between the application of PSAK 108 and the survival of sharia insurance companies partially, $b$. the positive influence between unit-linked products and the viability of sharia insurance companies partially, $c$. the positive influence between the application of PSAK 108 and unit-linked products with the survival of the Islamic insurance company together. The viability of sharia insurance companies will survive, if the consistent implementation of article 108 and sharia unit-linked products that are safe from the influence of the JCI in investing, and use good governance. The fact is from the data that there are companies that have large liquid assets that still survive, but there are also insurance companies with low capital that remain strong (high risk high return) in maintaining the going concen assumption.
\end{abstract}

Abstract

Keywords: Sharia Life Insurance, Composite Stock Price Index, PSAK 108, sharia unit-linked products, Risk of tomorrow.

Saran sitasi: Suyatna, N. (2021). Pengaruh PSAK 108, Produk Unit Linked terhadap Asumsi Going Concern Perusahaan Asuransi Syariah di Indonesia. Jurnal Ilmiah Ekonomi Islam, 7(02), 908-916. doi:http://dx.doi.org/10.29040/jiei.v7i2.2436

DOI: http://dx.doi.org/10.29040/jiei.v7i2.2436

\section{PENDAHULUAN}

Dalam menjalani kehidupan di dunia, walaupun sudah kecukupan secara materi namun terkadang merasa belum lengkap jika tidak dilengkapi dengan mengikuti program asuransi jiwa.

Menurut Ai Fitri Nurlatifah dan Sepky Mardian(Nurlatifah \& Mardian, 2016) yang dikutip dari Pusat Komunikasi Ekonomi Syariah, Allah telah memerintahkan manusia agar mampu menyiapkan bekal (proteksi) untuk kepentingan di masa depan supaya segala hal negatif baik dalam bentuk musibah, kecelakaan, kebakaran atau kematian dapat diminimalisir kerugiannya. Hal tersebut telah dicontohkan oleh Nabi Yusuf (QS. Yusuf : 46-49) ketika menakwilkan mimpi Raja Mesir tentang tujuh ekor sapi betina gemuk dimakan oleh tujuh sapi betina kurus yang memberikan pelajaran agar manusia mengadakan persiapan untuk menghadapi masa-masa sulit.
Menurut (Leliya \& Kurniasari, 2016) nasabah berminat berasuransi syariah karena di asuransi syariah tidak mengenal istilah dana hangus layaknya asuransi konvensional, nasabah asuransi syariah bisa mendapatkan uangnya kembali meskipun belum datang jatuh tempo karena konsep asuransi syariah adalah wadiah (titipan). Mengelola dana melalui asuransi syariah diyakini dapat terhindar dari unsur yang diharamkan Islam yaitu riba, gharar (ketidak jelasan dana) dan maysir (judi). Asuransi syariah dengan perjanjian diawal yang jelas dan transparan serta akad yang sesuai dengan syariah, dimana danadana premi asuransi yang terkumpul (tabarru') akan dikelola secara profesional oleh perusahaan asuransi syariah melalui investasi syariah dengan berlandaskan prinsip Syariah.

Kabar yang mengejutkan ada 5 kasus gagal bayar perusahaan asuransi jiwa, dengan berbagai alasan diantaranya (Hastuti, 2020):1) Ada 1 (satu) 


\section{Jurnal Ilmiah Ekonomi Islam, 7(02), 2021, 909}

perusahaan asuransi jiwa konvensional, melakukan miss management atau kesalahan mengelola perusahaan, 2) Ada 2 (dua) perusahaan asuransi jiwa konvensional, dengan alasan karena produk unit link, 3) Ada 1(satu) alasan kesehatan perusahaan (Risk Based Capital) dan rasio perimbangan investasi terhadap cadangan teknis dan utang klaim, dan 4) ada 1(satu) perusahaan asuransi jiwa tidak mampu lunasi klaim polis nasabah sebesar Rp 802 miliar. Yang perlu digaris-bawahi ada 2 perusahaan asuransi jiwa yang gagal bayar akibat mengelola produk unit link (asuransi dan investasi) disisi lain asuransi jiwa produk unit link sangat menguntungkan bagi nasabah. Bagaimana dengan perusahaan asuransi jiwa syariah, bisa mengalami hal yang sama?

Menurut Asosiasi Asuransi Jiwa Indonesia((AAJI), 2021), sampai dengan Kuartal I 2019, mencatat premi industri asuransi jiwa mencapai Rp 46,40 triliun. Dari jumlah itu porsi unitlink 63\%, sedangkan $37 \%$ dari tradisional. Padahal tahun sebelumnya, porsi tradisional masih $43 \%$, sementara $57 \%$ adalah unitlink. Hal ini menunjukan peningkatan minat terhadap produk unit link. Masyarakat menaruh harapan besar terhadap produk unit link ini, tinggal bagaimana pihak perusahaan asuransi jiwa memberdayakan dana masyarakat tersebut agar berkembang secara optimal. Beberapa alternatif pemberdayaan dana masyarakat atas asuransi jiwa dengan produk unit link diantaranya: 1) Reksa Dana, 2) Saham, 3) Properti Investasi, 4) Deposito berjangka, 5) Surat Utang Negara (SUN), 6) Obligasi Korporasi, 7) Penyertaan Langsung, 8) Pinjaman Polis, 9) Medium Term Note (MTN), 10) Efek Beragunan Aset. Dari kesemuanya itu yang paling dominan $(45,32 \%)$ adalah Reksa Dana, sebagai sampel Komoposisi portofolio investasi PT Jiwasraya, 2017-2019(Lokadata, 2019). Sementara untuk perusahaan asuransi syariah, alternatif pemberdayaan dana masyarakat atas asuransi jiwa syariah dengan produk unit link diantaranya: 1) Reksa Dana Syariah, 2) Saham Syariah, 3) Sukuk Ritel, 4) Deposito Syariah, 5) Emas atau logam mulia 6) Properti Syariah, yang paling dominan pilihan perusahaan asuransi jiwa dalam berinvestasi pada Reksa Dana Syariah yang return-nya sangat tergantung fluktuasi Indeks Harga Saham Gabungan (IHSG), Indeks LQ45 dan IDX-30.

\section{Tujuan dan manfaat kegiatan}

Berdasarkan penomena tersebut, peneliti ingin mengetahui penyebab terjadinya gagal bayar dan ingin mengetahui serta menganalisis berapa besar pengaruh PSAK 108 dan Produk Unit Linked terhadap Asumsi Going Concern baik secara parsial maupun simultan sehingga dapat diperoleh cara antisipasi gagal bayar. dan memberi masukan dalam memilih produk unit link baik untuk perusahaan asuransi syariah maupun konvensional.

\section{Rumusan Masalah}

Rumusan masalah penelitian yang akan dilakukan sebagai berikut :

1) Seberapa besar pengaruh PSAK 108 terhadap Asumsi Going Concern Perusahaan Asuransi Syariah di Indonesia?

2) Seberapa besar pengaruh Produk Unit Linked terhadap Asumsi Going Concern Perusahaan Asuransi Syariah di Indonesia?

3) Seberapa besar pengaruh PSAK 108 dan Produk Unit Linked terhadap Asumsi Going Concern Perusahaan Asuransi Syariah di Indonesia secara simultan?

\section{Tinjauan Pustaka}

Menurut Undang-Undang Pasar Modal No. 8 Tahun 1995, pasal 1 ayat (27) didefinisikan bahwa Reksa Dana adalah wadah yang dipergunakan untuk menghimpun dana dari masyarakat pemodal untuk selanjutnya diinvestasikan dalam portofolio efek oleh manajer

investasi. Ada tiga hal yang terkait dari definisi tersebut yaitu, Pertama, adanya dana dari masyarakat pemodal. Kedua, dana tersebut diinvestasikan dalam portofolio efek, dan Ketiga, dana tersebut dikelola oleh manajer investasi(OJK, 2010).

Menurut Rudiyanto(Rudiyanto, 2020) selain Indeks Harga Saham Gabungan (IHSG), indeks saham acuan yang banyak dikenal dan digunakan oleh industri reksa dana sebagai acuan kinerja adalah LQ45 dan IDX-30. Indeks LQ45 adalah salah satu index yang populer di Indonesia. Indeks ini mengukur kinerja harga dari 45 saham yang memiliki likuiditas tinggi dan kapitalisasi pasar besar serta didukung oleh fundamental perusahaan yang baik. Indeks LQ45 merupakan gabungan dari saham-saham biasa dan saham syariah. Menurut Mang Amsi(Mang Amsi, 2020), ada 7 Saham LQ45 Syariah Unggul yang memiliki performa mengungguli kinerja Indeks Harga Saham Gabungan (IHSG) dalam lebih dari seperempat abad terakhir.

Menurut Ikatan Akuntan Indonesia(DSAK-IAI, 2016), PSAK 108 yang mengatur pengakuan, pengukuran, penyajian, dan pengungkapan transaksi 
asuransi syariah. Transaksi asuransi syariah yang dimaksud dalam Pernyataan ini adalah transaksi yang terkait dengan kontribusi peserta, surplus dan defisit underwriting, penyisihan teknis, dan saldo dana tabarru'.

Dalam hal pengakuan awal, kontribusi peserta diakui sebagai pendapatan dari dana tabarru' dengan ketentuan sebagai berikut:

a. untuk akad asuransi syariah jangka pendek, kontribusi peserta diakui sebagai pendapatan dari dana tabarru' sesuai periode akad asuransi;

b. untuk akad asuransi syariah jangka panjang, kontribusi peserta diakui sebagai pendapatan dari dana tabarru' pada saat jatuh tempo pembayaran dari peserta.

Penyisihan teknis diukur sebagai berikut:

a. Kontribusi yang belum menjadi hak dihitung secara individual dari setiap pertanggungan dan besarnya penyisihan ditetapkan secara proporsional dengan jumlah proteksi yang diberikan.

b. Manfaat polis masa depan dihitung dengan mencerminkan estimasi pembayaran seluruh manfaat yang diperjanjikan dan penerimaan kontribusi peserta di masa mendatang, dengan mempertimbangkan estimasi tingkat imbal hasil investasi dana tabbaru'.

c. Klaim yang masih dalam proses diukur sebesar estimasi jumlah klaim yang masih dalam proses oleh entitas pengelola. Jumlah perkiraan tersebut harus mencukupi untuk mampu memenuhi klaim yang terjadi dan dilaporkan sampai dengan akhir periode pelaporan.

d. Klaim yang terjadi tetapi belum dilaporkan diukur sebesar estimasi jumlah klaim yang akan dibayarkan pada tanggal pelaporan berdasarkan pada pengalaman masa lalu yang terkait dengan klaim paling kini yang dilaporkan.

e. Perhitungan penyisihan teknis tersebut memasukan bagian reasuransi atas klaim.

Menurut Liyanto Sudarso(Sudarso, 2018) yang tidak kalah penting dan perlu dipertimbangakan dalam berinvestasi di reksa dana adalah kestabilan imbal hasil investasi reksa dana pasar uang untuk memaksimalkan imbal hasil investasi dan ketenangan psikologi para investor dalam berinvestasi.

Menurut Nurlatifah \& Mardian (Nurlatifah \& Mardian, 2016), hasil dari penelitian ini dapat disimpulkan bahwa size, leverage, liquidity, tangibility, volume of capital dan loss ratio dapat berpengaruh terhadap Surplus On Contribution (SOC) perusahaan-perusahaan asuransi syariah di Indonesia. Oleh karena itu, untuk perusahaan asuransi syariah yang ingin meningkatkan kinerja keuangannya, hendaknya melakukan analisis terhadap faktor-faktor yang mempengaruhi kinerja keuangan perusahaan seperti yang sudah dijelaskan diatas, sehingga dapat merumuskan strategi yang tepat untuk lebih meningkatkan kinerja keuangannya.

Menurut Mei Santi (Santi, 2018), praktik asuransi syariah unit link di Indonesia telah mengacu pada fatwa DSN MUI dan didampingi oleh dewan pengawas syariah (DPS) yang telah ditunjuk untuk masing-masing perusahaan, serta di bawah pengawasan otoritas jasa keuangan (OJK) sehingga diharapkan dalam pelaksanaannya sesuai dengan ketentuan yang berlaku di Indonesia. Dan dapat mendorong pertumbuhan perusahaan jasa asuransi syariah unit link yang semakin kokoh dan menjadi tonggak perekonomian di Indonesia.

Menurut Surat Edaran OJK No. 25 /SEOJK.05/2017(OJK, 2017), terdapat beberapa risiko yang harus dinilai diantaranya; 1 ). Risiko Kredit yaitu risiko kemungkinan adanya kehilangan atau penurunan nilai asset, 2) Risiko Likuiditas yaitu risiko ketidakseimbangan antara proyeksi arus aset dan arus Liabilitas yang timbul karena adanya ketidaksesuaian antara besar dan saat jatuh tempo aset dengan besar dan saat jatuh tempo Liabilitas, 3) Risiko Pasar yaitu risiko kemungkinan adanya kerugian akibat terjadinya perubahan harga pasar atas aset Perusahaan, perubahan nilai tukar mata uang asing dan perubahan tingkat hasil investasi sebagai dampak dari volatilitas dan Likuiditas pasar, 4) Risiko Asuransi yaitu risiko kemungkinan kegagalan Perusahaan memenuhi kewajiban kepada pemegang polis atau peserta sebagai akibat dari ketidakcukupan proses seleksi risiko (underwriting), penetapan kontribusi (pricing), dan/atau penanganan klaim, 5) Risiko Operasional yaitu risiko kemungkinan yang disebabkan adanya ketidakcukupan dan/atau tidak berfungsinya proses intern, kesalahan sumber daya manusia, kegagalan sistem, dan/atau adanya masalah ekstern yang mempengaruhi operasional Perusahaan, termasuk pengelolaan dana investasi yang bersumber dari Produk Asuransi Yang Dikaitkan dengan Investasi (PAYDI) yang dikenal dengan Produk Unit Link. Semakin komplek struktur Perusahaan, risiko operasional akan meningkat. Risiko tersebut jika 


\section{Jurnal Ilmiah Ekonomi Islam, 7(02), 2021, 911}

tidak dikelola dengan baik akan berakibat pada kelangsungan hidup (going concern) suatu perusahaan terancam.

Selain risiko tersebut diatas yang perlu dipertimbangkan adalah risiko berinvestasi di sahan, diantaranya(Mang Amsi, 2020: 127-130) : 1) Capital Loss, kondisi ketika investor menjual lebih rendah dari harga beli, 2) Tidak mendapat deviden, dimana perusahaan membukukan kerugian, 3) Keluar dari Daftar Efek Syariah, Setiap enam bulan sekali, komposisi indeks saham syariah di-reniu ulang oleh OJK dan DSN-MUI. Dampaknya, ada beberapa saham yang masuk dan keluar perhitungan index saham syariah karena tidak lagi dikategorikan sebagai saham syariah, 4) Suspensi(Listyorini, 2019), Suspensi saham adalah penghentian sementara perdagangan saham oleh otoritas bursa, dalam hal ini BEI, pada kurun waktu tertentu sehingga investor tidak bisa membeli ataupun menjual saham sampai ada pemberitahuan pencabutan suspensi, 5) Delisting, Delisting adalah penghapusan pencatatan saham di Bursa Efek Indonesia(BEI), setelah dilisting sah, saham tidak bisa lagi ditransaksikan lagi di BEI, 6) Likuidasi, Likuidasi terjadi ketika perusahaan yang sahamnya dimiliki dinyatakan bangkrut oleh pengadilan, atau perusahaan tersebut dibubarkan. Kerugian seperti hal tersebut diatas penyebab dana investasi yang bersumber dari konsumen atau nasabah berkurang, hal ini bisa saja menjadi pemicu gagal bayar baik pada perusahaan asuransi jiwa konvesional maupun perusahaan asuransi syariah, jika manager investasi lengah dalam memilih jenis investasi dan tingkan risikonya.

Going concern adalah kelangsungan hidup suatu entitas. Kelangsungan hidup entitas dianggap sebagai kemampuan perusahaan mempertahankan kegiatan usahanya dalam jangka waktu panjang dan tidak akan dilikuidasi dalam jangka waktu pendek.

Menurut Harahap (Harahap, 2015) going concern adalah continuity, yaitu :

"Suatu postulat yang menganggap bahwa suatu perusahaan akan terus melaksanakan operasinya sepanjang penyelsaian proyek, perjanjian, dan kegiatan yang sedang berlangsung. Perusahaan dianggap tidak berhenti, ditutup atau dilikuidasi di masa yang akan datang, perusahaan dianggap akan hidup untuk jangka waktu yang tidak terbatas."

Menurut Belkaoui (Belcaoui, 2006) going concern adalah :
"Suatu dalil yang menyatakan bahwa kesatuan usaha akan menjalankan terus operasinya dalam jangka waktu yang cukup lama untuk mewujudkan proyeknya, tanggung jawab serta aktivitas-aktivitasnya yang tidak berhenti."

Dalil asumsi Going Concern atau dalil kontinuitas menganggap bahwa kesatuan usaha akan menjalankan terus-menerus operasinya dalam jangka waktu yang cukup lama untuk mewujudkan proyeknya, tanggungjawab serta aktivitas-aktivitas yang tidak berhenti. Kesatuan usaha tidak diharapkan dilikuidasi secepatnya di masa datang. Jangka waktu hidup unit usaha dalam pernyataan tersebut adalah relatif dengan pernyataannya cukup lamanya itu. Hal ini secara logis dan praktis adalah suatu pernyataan yang terbukti dengan sendirinya.

Dalam Islam terdapat pandangan bahwa segala sesuatu pasti binasa, kecuali Allah (Qur'an, 28:88), semua yang ada di bumi akan binasa (Qur'an, 55:26) dan hanya Allah tuhanmu sajalah yang tetap kekal yang mempunyai kebesaran dan kemuliaan (Qur'an, 55:27). Di sini tersirat bahwa selain allah pada masa yang akan datang, cepat atau lambat pasti semua akan binasa, mengandung perintah ubudiyah (rasa penghambaan) manusia hanyalah mengabdi kepada Allah saja, sedangkan dalam muamalah (hubungan dengan sesama mahluk), hendaknya mempunyai pandangan tidak kekal, meskipun waktunya tidak dapat ditentukan. Merujuk dengan berbagai era kenabian atau kerasulan, maka Allah mempergilirkan masa suatu kerasulan/kenabian ke masa kenabian/kerasulan berikutnya, dapat mengidentifikasikan bahwa kontinuttas urusan dunia yang, diwakilkan oleh manusia yang terpilih. Jika disimak dari penciptaan siang dan malam, juga menunjukkan kontinuitas dari waktu usaha yang ada di bumi.

Hal ini seperti dalam Al Qur'an 17:12, Dan Kami telah jadikan malam dan siang sebagai dua tanda, lalu kami hapus tanda malam dan Kami jadikan tanda siang itu terang benderang, sehingga kamu dapat berusaha mencari karunia Tuhanmu dan agar kamu dapat mengetahui bilangan tahun dan perhitungan waktu.

Dengan adanya asumsi going concern maka suatu badan usaha dianggap akan mampu mempertahankan kegiatan usahanya dalam jangka waktu panjang, tidak akan dilikuidasi dalam jangka waktu pendek. 


\section{Hipotesis}

Hipotesis yang digunakan terhadap rumusan masalah penelitian diatas sebagai berikut :

\section{a. Mengetahui hubungan PSAK 108 terhadap Asumsi Going Concern Perusahaan Asuransi Syariah di Indonesia}

Direktur Eksekutif Asosiasi Asuransi Syariah Indonesia (AASI) Erwin Noekman mengaku khawatir dengan ramainya berita gagal bayar asuransi besar yang akan mempengaruhi citra pelaku asuransi lain khususnya bisnisnya yang lebih kecil. Dia mengkhawatirkan industri asuransi syariah akan ikut mendapatkan citra negatif dari masyarakat. Strategi yang dipilih adalah melakukan kampanye asuransi syariah untuk tolong menolong. Menurutnya di tengah berbagai bencana saat ini minat masyarakat untuk berdonasi tinggi seperti melakukan wakaf dan membantu korban bencana.

Kinerja asuransi syariah pada Desember 2020 untuk nilai aset industri tercatat sebesar Rp 44,4 triliun, yang turun $2,2 \%$ (yoy) dibandingkan dengan 2019 senilai Rp 45,5 triliun. Kinerja ini dinilai masih berada dalam kondisi yang wajar, mengingat besarnya dampak pandemi Covid19 bagi perekonomian.

H1: Terdapat pengaruh PSAK 108 terhadap asumsi going concern pada perusahaan asuransi syariah di Indonesia

b. Mengetahui hubungan Produk Unit Linked terhadap Asumsi Going Concern Perusahaan Asuransi Syariah di Indonesia

Sekitar tiga juta nasabah memutuskan 'angkat kaki' dari produk asuransi yang dikaitkan dengan investasi (PAYDI) atau unit linked sepanjang 2020. Kondisi ini berbanding lurus dengan lonjakan aduan nasabah produk tersebut dalam tiga tahun terakhir.

Otoritas Jasa Keuangan (OJK) mencatat, laporan masyarakat terkait unit link meningkat dari 360 pada 2019 menjadi 593 di tahun lalu. Memasuki bulan keempat tahun ini, total laporan yang masuk bahkan sudah mencapai 293 atau dua pertiga dari total laporan di 2019.

H2: Terdapat pengaruh Produk unit linked terhadap asumsi going concern pada perusahaan asuransi syariah di Indonesia. c. Mengetahui hubungan PSAK 108 dan Produk Unit Linked terhadap Asumsi Going Concern Perusahaan Asuransi Syariah di Indonesia.

H3: Terdapat pengaruh PSAK 108 dan Produk Unit Linked terhadap Asumsi Going Concern Perusahaan Asuransi Syariah di Indonesia secara simultan.

\section{METODE PENELITIAN}

Metode yang digunakan oleh penulis dalam penelitian ini adalah metode deskriptif, yaitu suatu metode yang menggambarkan dan melukiskan keadaan yang sebenarnya untuk memperoleh data yang kemudian diolah, dianalisa dan diproses lebih lanjut dengan dasar teori yang telah dipelajari sehingga dari data tersebut dapat diambil suatu kesimpulan.

Jumlah sampel yang diambil sebanyak 4 perusahaan asuransi syariah dari 24 perusahaan asuransi syariah dengan kriteria permodalan lebih dari 2 triliun, 2 perusahaan asuransi syariah dan yang permodalan kurang dari 2 triliun serta memiliki produk Unit Linked selama 12 periode triwulan laporan keuangan yaitu 3 tahun 2018- 2020 per satu perusahaan asuransi. Sumber data yang digunakan dalam penelitian ini adalah data sekunder. Data sekunder diperoleh dari dokumentasi periode yaitu tahun 2018, 2019, 2020 selama 12 periode triwulan per perusahaan asuransi yang menjadi sample yaitu PT.Allianz Life Syariah, PT.Takaful Keluarga Syariah, PT. AXA Finance Life Syariah, PT. Prudential Syariah . Data perusahaan asuransi syariah diperoleh bersumber Otoritas Jasa Keuangan (OJK) dan web site masing-masing perusahaan asuransi syariah yang menjadi sample penelitian.

Analisis data menggunakan Regresi Data Panel dengan tahapan analisis data yang dilakukan dalam penelitian ini adalah sebagai berikut:

a. Menghitung dan menginterpretasikan going concern perusahaan asuransi terkait dan membandingkannya dari tahun ke tahun yaitu 2018 , 2019, 2020 selama 12 periode triwulan. Rasio keuangan yang dihitung terdiri dari: a. Rasio Solvabilitas; b.Rasio Profitabilitas masingmasing perusahaan asuransi syariah.

b. Menghitung dan menginterpretasikan PSAK 108 sesuai dengan ketentuan pemerintah pada perusahaan asuransi terkait dan membandingkannya Dana Tabaruu' selama 12 
periode triwulan, 3 tahun berturut-turut yaitu tahun 2018, 2019 dan 2020.

c. Menghitung dan menginterpretasikan Produk Unit Linked pada perusahaan asuransi terkait dan membandingkannya Investasi peserta selama 12 periode triwulan, 3 tahun berturut-turut yaitu tahun 2018, 2019 dan 2020.

Pengelolaan data bertujuan untuk mengidentifikasi dan menganalisis. Dalam usaha mencapai tujuan, maka penulis menggunakan analisis Regresi Data Panel dimaksud untuk melihat apakah variabel bebas (independent) secara individu mempunyai pengaruh terhadap variabel tak bebas (dependent).

Metode yang dipakai adalah regresi terhadap data panel dengan Formula umum antar variabel adalah $\mathrm{Y}$ $=\mathrm{a}+\mathrm{b} \mathrm{X} 1$. Karena memakai variabel intervening berupa X2, maka formulanya mengikuti sebagai berikut:

$$
\mathbf{Y}=\mathbf{a}+\mathbf{b} \mathbf{X 1}+\mathbf{c X 2} \ldots \mathrm{Xn} \text {. }
$$

Dari persamaan di atas dapat diaplikasikan ke model dibawah ini :

$$
\mathrm{Y}=\mathbf{a}+\mathbf{b} \mathbf{X 1}+\mathbf{c} \mathbf{X} 2
$$

Dimana:

$\mathrm{a}=$ konstanta,

$\mathrm{b}=$ koefisien variabel Unit Link,

$\mathrm{c}=$ koefisien variabel PSAK 108,

$\mathrm{X} 1=$ Produk Unit Link

$\mathrm{X} 2$ = PSAK 108

\section{HASIL DAN PEMBAHASAN}

\subsection{Hasil penelitian}

Hasil Penelitian yang diperoleh sebagai berikut :

\begin{tabular}{ccccc}
\hline Variable & Coefficient & Std. Error & t-Statistic & Prob: \\
\hline C & -2688803 & 374052.9 & -7.188294 & 0.0000 \\
X1 & 1.047657 & 0.098842 & 10.59932 & 0.0000 \\
X2 & 0.848960 & 0.387023 & 2.193562 & 0.0323 \\
\hline
\end{tabular}

Tabel 1.

Dari Tabel 1, tersebut terdapat pengaruh: 1. Terdapat pengaruh antara PSAK 108 terhadap Asumsi Going Concern Perusahaan Asuransi Syariah di Indonesia sebesar 1.04765688217 untuk setiap perubahan variable PSAK 108, 2.Terdapat pengaruh Produk Unit Linked terhadap Asumsi Going Concern Perusahaan Asuransi Syariah di Indonesia sebesar 1.04765688217 untuk setiap perubahan variable Produk Unit Link, 3. Terdapat pengaruh PSAK 108 dan Produk Unit Linked terhadap Asumsi Going
Concern Perusahaan Asuransi Syariah di Indonesia secara simultan, karena masing-masing Probabilitas dibawah 0,05 .

Dengan persamaan regresi data panel, sebagaui berikut :

$$
\begin{gathered}
\mathrm{Y}=-2.688 .802,59294+1,04765688217 * \mathrm{X} 1+ \\
0,848959673587 * \mathrm{X} 2+[\mathrm{CX}=\mathrm{F}]
\end{gathered}
$$

Dimana Y adalah Asumsi Going Concern, X1 adalah Produk Unit Link daan X2 adalah PSAK 108.

Atas persamaan tersebut dengan meningkatnya nilai variabel Produk Unit Link sebesar Rp 1 dan nilai variabel PSAK 108 sebesar Rp 1,maka tingkat profitabilitas sebagai gambaran asumsi going concern akan menjadi sebesar Rp -2.688.801,10 kelangsungan hidup perusahaan terancam. Perlu usaha lebih keras baik dalam meningkatkan efesiensi dan effektifitas usaha. Hasil Analisa Laporan Keuangan 4 perusahaan Asuransi Syariah yang menjadi sample penelitian, terdapat kerugian yang cukup signifikat pada periode Q1,Q2 dan Q3 tahun 2020 baik dari aktivitas produk asuransi jiwa syariah biasa maupun asuransi produk Unit Link. Hal ini akibat IHSG saham yang menurun. Semakin banyak produk Unit Link, semakin banyak dampak kerugian yang dideritanya.

\subsection{Pembahasan}

Produk Unit Link merupakan produk harapan, baik Produk Unit Link konvensional maupun Produk Unit Link syariah. Bisa jadi saling menguntungkan antara perusahaan asuransi jiwa dengan nasabahnya, namun permasalahan bisa ditimbulkan oleh pihak ketiga yaitu Manajemen Investasi yang ditunjuk oleh perusahaan asuransi untuk mengelola investasi yang bersumber dari produk unit link yang dikuasakan kepada manajemen investasi tersebut. Ada pengalaman beberapa perusahaan asuransi, sebagai berikut :

a. PT. Bakrie Life terjadi pada Tahun 2008, asuransi milik Grup Bakrie ini tercatat gagal bayar gagal atas produk Diamond Investa Bakrie Life (Unit Linked) . Gagal bayar ini terjadi tahun 2010. Saat itu, manajemen Bakrie Life beralasan gagal bayar yang terjadi karena imbas krisis ekonomi 2008. Hal ini bisa terjadi karena investasi khususnya Reksa Dana Saham yang sangat tergantung pada performa IHSG. Melihat pergerakan IHSG yang lebih panjang dari tahun 2008-2017, telah terjadi koreksi yang cukup dalam pada tahun 2008 karena krisis Sub Prime Mortgage di Amerika Serikat (Sudarso, 2018: 57). 


\section{Jurnal Ilmiah Ekonomi Islam, 7(02), 2021, 914}

b. PT. Asuransi Jiwasraya(Nurdiana, 2019), Jiwasraya menyerah, dan menyatakan tak sanggup memenuhi kewajiban pembayaran yang nilainya (gagal bayar) mencapai Rp 12,4 triliun per Desember 2019. Jiwasraya sejatinya memiliki asset. Hanya, asset Jiwasraya menyusut menjadi Rp 2 triliun, dari sebelumnya Rp 25 triliun lantaran salah dalam penempatan investasi. Isi portfolio Asuransi Jiwasraya mayoritas adalah saham-saham yang tak likuid. Direktur Utama Asuransi Jiwasraya. Hexana Tri Sasongko mengatakan, asuransi BUMN ini gagal mengelola asetnya, utamanya dalam memilih instrumen investasi khususnya saham. Harusnya maksimal mengalokasikan untuk saham 20\%, seharusnya saham blue chips (saham unggulan), surat utang negara (government bond), instrumen Bank Indonesia minimal $30 \%$. Sayangnya, yang terjadi alokasi mayoritas ke saham, itu pun saham dengan rendah mencapai $50 \%$, sedangkan government bonddi $15 \%$. Keputusan ini kini berefek besar karena sebagian besar dana terjebak dalam saham-saham yang nilainya di bawah Rp 50 per saham. Bahkan, saat ini saham-saham tersebut telah mendapat suspensi (pembekuan atau penghentian sementara aktivitas perdagangan saham) dari BEI.

Dengan demikian penempatan dana konsumen perlu adanya pengelolaan yang tepat dalam penentuan jenis investasi, agar selain hasil yang optimal juga tingkat likuiditas dan arus kas perusahaan asuransi tetap terjaga dengan baik.

Untuk perusahaan asuransi syariah agar tidak mengalami hal yang sama, ada beberapa pendapat ahli diantanya:

a. Menurut Wakil Presiden Ma'ruf Amin(Purnamasari, 2020) mengatakan, tata kelola usaha yang baik atau good corporate governance (GCG) dalam asuransi syariah harus diterapkan untuk menghindari kasus gagal bayar.

b. Menurut Aziz Rahardyan(Aziz Rahardyan, 2021), Asuransi syariah dinilai lebih kebal terhadap masalah gagal bayar. Hal ini salah satunya karena asuransi syariah telah memiliki dana talangan internal (qardh).

c. Menurut Tatang Nurhidayat(Aziz Rahardyan, 2021), Ketua Asosiasi Asuransi Syariah Indonesia (AASI) menjelaskan artinya prinsip keterbukaan dan akuntabilitas industri asuransi syariah diakui dunia sebagai aturan yang prudent.

d. Menurut Erwin Noekman(Hafid Fuad, 2021), Direktur Eksekutif Asosiasi Asuransi Syariah Indonesia atau AASI bahwa gagal bayar tidak ada di asuransi syariah tapi literasi asuransi syariah masih minim. Strategi yang dipilih adalah melakukan kampanye asuransi syariah untuk tolong menolong. Menurutnya di tengah berbagai bencana saat ini minat masyarakat untuk berdonasi tinggi seperti melakukan wakaf dan membantu korban bencana. Jadi perusahaan asuransi syariah merupakan lembaga mediasi antara konsumen dan masyarakat yang memerlukan pertolongan.

Langkah OJK dalam menangani permasalahan gagal bayar pada perusahaan asuransi di Indonesia. Penanganan PT. Asuransi Jiwa Kresna Life, ada tiga poin yang disampaikan OJK(Sidik, 2020) dalam mengatasi kasus gagal bayar. Pertama, menurunkan konsentrasi penempatan investasi pada pihak terafiliasi Grup Kresna. Kedua, menyelesaikan kewajiban terhadap seluruh pemegang polis, antara lain dengan membuat kesepakatan penyelesaian kewajiban. Ketiga, memenuhi ketentuan Rasio Pencapaian Solvabilitas minimum sebesar $100 \%$. Adanya ketidak-transfarannan dalam berinvestasi, sehingga dapat merugikan pihak nasabah dan melanggar kebijakan OJK dalam berinvestasi. Bagian Ketiga Aset Yang Diperkenankan Dalam Bentuk Investasi Pasal 5 poin 2 (OJK, 2016) bahwa : Aset Yang Diperkenankan dalam bentuk investasi harus ditempatkan pada jenis: a. deposito berjangka pada Bank, BPR, dan BPRS, termasuk deposit on call dan deposito yang berjangka waktu kurang dari atau sama dengan 1 (satu) bulan; b. sertifikat deposito pada Bank; c. saham yang tercatat di bursa efek; d. obligasi korporasi yang tercatat di bursa efek; e. MTN; f. surat berharga yang diterbitkan oleh Negara Republik Indonesia; g. surat berharga yang diterbitkan oleh negara selain Negara Republik Indonesia; h. surat berharga yang diterbitkan oleh Bank Indonesia; i. surat berharga yang diterbitkan oleh lembaga multinasional yang Negara Republik Indonesia menjadi salah satu anggota atau pemegang sahamnya; j. reksa dana; k. efek beragun aset; 1 . dana investasi real estat berbentuk kontrak investasi kolektif; m. transaksi surat berharga melalui repurchase agreement (REPO); n. penyertaan langsung pada perseroan 


\section{Jurnal Ilmiah Ekonomi Islam, 7(02), 2021, 915}

terbatas yang sahamnya tidak tercatat di bursa efek; o. tanah, bangunan dengan hak strata (strata title), atau tanah dengan bangunan, untuk investasi; $p$. pembiayaan melalui mekanisme kerja sama dengan Pihak lain dalam bentuk kerjasama pemberian kredit (executing); q. emas murni; r. pinjaman yang dijamin dengan hak tanggungan; dan/atau s. pinjaman polis. Jadi berinvestasi pada perusahan group, atau induk perusahaan asuransi tidak diperbolehkan. Secara umum Rasio Pencapaian Solvabilitas minimum sebesar $100 \%$ harus dipertahankan, tidak hanya perusahaan asuransi konvensional saja, tapi berlaku untuk perusahaan asuransi prinsip syariah juga.

Dari hasil penelitian tidak ada hal yang baru, semua terumuskan dalam aturan dan ketentuanketentuan yang telah dikeluarkan oleh Otoritas Jasa Keuagan. Akhirnya bagaimana perusahan asuransi mematuhinya. Tidak terlepas dari hal tersebut, nasabah disarankan cerdas dalam memilih perusahaan asuransi jiwa terlepas asuransi jiwa murni atau produk unit link. Kenyataan dari data yang ada perusahaan yang memiliki aset likuid yang besar masih bertahan, tapi ada juga perusahaan asuransi bermodal rendah yang tetap bertahan (high risk high return) dalam mempertahankan asumsi going concen. Dan dari data yang ada, perusahaan yang mengalami gagal bayar, justru perusahaan asuransi jiwa yang tata kelola kurang baik.

\section{KESIMPULAN}

Dari hasil penelitian dapat disimpulkan bahwa terdapat pengaruh :1. PSAK 108 terhadap Asumsi Going Concern Perusahaan Asuransi Syariah di Indonesia untuk setiap perubahan variable PSAK 108, 2. Produk Unit Linked terhadap Asumsi Going Concern Perusahaan Asuransi Syariah di Indonesia untuk setiap perubahan variable Produk Unit Link, 3. PSAK 108 dan Produk Unit Linked terhadap Asumsi Going Concern Perusahaan Asuransi Syariah di Indonesia secara simultan, karena masing-masing Probabilitas dibawah standar ketentuan.

Dalam tata kelola perusahaan asuransi ada 3 komponen yang terlibat yaitu ; nasabah, perusahaan asuransi dan manajemen investasi, karena dalam perusahaan asuransi tidak bisa mengelola dana nasabah secara mandiri, harus melibatkan pihak ketiga(manajemen investasi), agar dana investasi yang bersumber dari nasabah dapat berkembang. Namun dalam perjalannya investasi itu sangat komplek sehingga dikenal high risk high return, ingin untung besar resiko juga besar bisa sampai mengait perusahaan asuransi gagal bayar. Tidak jarang manajemen investasi yang mengambil risiko tinggi. Risiko di pasar modal bisa diakibatkan bencana wabah seperti sekarang ini covid-19. Sehingga Q1,Q2,Q3 tahun 2020 semua perusahaan asuransi jiwa yang menginvestasikan dana pada pasar modal mengalami kerugian, karena kebanyakan investasi pada Dana Reksa, dimana dana reksa terkait IHSG, maka terkena dampak kerugian.

Untuk menghindari perusahaan asuransi gagal bayar, disarankan perusahaan asuransi yang tata kelola perusahaannya baik, banyak indikator diantaranya, menyampaikan laporan keuangan dengan konsisten, konten laporan menyampaikan dan menggambarkan kinerja yang baik,dll.

\section{UCAPAN TERIMA KASIH}

Saya sampaikan banyak terima kasih kepada rekan-rekan di Universitas Ma'soem Sumedang, atas dukungan moril maupun materil.

\section{REFERENSI}

(AAJI), A. A. J. I. (2021). Minat masyarakat bergeser, kontribusi premi produk asuransi jiwa tradisional turun. AAJI. https://keuangan.kontan.co.id/news/minatmasyarakat-bergeser-kontribusi-premi-produkasuransi-jiwa-tradisional-turun

Aziz Rahardyan. (2021). Asuransi Syariah Lebih Kebal Gagal Bayar, Kok Bisa? - Finansial Bisnis.com. Bisnis.Com. https://finansial.bisnis.com/read/20210202/215/ 1351335/asuransi-syariah-lebih-kebal-gagalbayar-kok-bisa

Belcaoui, A. (2006). Teori Akuntansi. Salemba Empat.

DSAK-IAI. (2016). PSAK:108 Akuntansi Transaksi Asuransi Syariah (Jakaera). Ikatan Akuntan Indonesia.

Hafid Fuad. (2021). Tak Ada Gagal Bayar di Asuransi Syariah, Tapi Tetap Terkena Citra Negatif. IDX Channel.

https://www.idxchannel.com/syariah/tak-adagagal-bayar-di-asuransi-syariah-tapi-tetapterkena-citra-negatif

Harahap, S. S. (2015). Teori Akuntansi. Rajawali Pers. 
Jurnal Ilmiah Ekonomi Islam, 7(02), 2021, 916

Hastuti, R. K. (2020). Kacau! Gagal Bayar 5 Asuransi Ini Bikin Nasabah Teriak. CNBC Indonesia. https://www.cnbcindonesia.com/market/202008 16100319-17-180132/kacau-gagal-bayar-5asuransi-ini-bikin-nasabah-teriak

Leliya, \& Kurniasari, M. (2016). Minat Masyarakat Berasuransi Syariah di Asuransi Prudential. Jurnal Dakwah Dan Komunikasi, 55.

Listyorini. (2019). Mengenal Istilah Suspensi Saham. https://investor.id/investory/mengenal-istilahsuspensi-saham

Lokadata. (2019). Komposisi Portofolio Investasi PT Jiwasraya, 2017-2019. Lokadata. https://lokadata.id/data/komoposisi-portofolioinvestasi-pt-jiwasraya-2017-2019-1576835496

Mang Amsi. (2020). Berkah dengan Investasi Syariah: Saham Syariah Kelas Pemula, Meretas Jalan Investasi di Pasar Modal (Yulian Masda (ed.)). PT. Elex Media Komputindo.

Nurdiana, T. (2019). Inilah 4 kasus gagal bayar besar asuransi jiwa di Indonesia - Page all. Https://Keuangan.Kontan.Co.Id/News/Inilah-4Kasus-Gagal-Bayar-Besar-Asuransi-Jiwa-DiIndonesia?Page $=$ all. https://keuangan.kontan.co.id/news/inilah-4kasus-gagal-bayar-besar-asuransi-jiwa-diindonesia? page $=$ all

Nurlatifah, A. F., \& Mardian, S. (2016). Kinerja Keuangan Perusahaan Asuransi Syariah di Indonesia, Akuntabilitas, 9(1), 74-75. https://doi.org/10.15408/akt.v9i1.3590

OJK. (2010). Undang-undang Nomor 8 Tahun 1995 tentang Pasar Modal. OJK. https://www.ojk.go.id/id/kanal/pasarmodal/regulasi/undang-undang/Pages/undangundang-nomor-8-tahun-1995-tentang-pasarmodal.aspx
OJK. (2016). POJK Nomor 71/POJK.05/2016 Kesehatan Keuangan Perusahaan Asuransi dan Perusahaan Reasuransi, Otoritas Jasa Keuangan.

OJK. (2017). SE. OJK No. 25 /SEOJK.05/2017, Tentang Pedoman Perhitungan Jumlah Dana Tabarru' dan Dana Tanahud Minimum Berbasis Risiko dan Modal Minimum Berbasis Risiko bagi Perusahaan Asuransi dan Perusahaan Reasuransi dengan Prinsip Syariah.

Purnamasari, D. M. (2020). Ma'ruf Amin Ingatkan Pelaku Asuransi Syariah untuk Hindari Kasus Gagal Bayar. Kompas.Com. https://nasional.kompas.com/read/2020/06/30/11 090671/maruf-amin-ingatkan-pelaku-asuransisyariah-untuk-hindari-kasus-gagal-bayar

Rudiyanto. (2020). Ini yang Terjadi pada Reksa Dana saat Indeks LQ45 dan IDX30 Dievaluasi Halaman all - Kompas.com. Kompas.Com. https://money.kompas.com/read/2020/08/03/193 913626/ini-yang-terjadi-pada-reksa-dana-saatindeks-lq45-dan-idx30-dievaluasi?page=all

Santi, M. (2018). Penerapan Asuransi Syariah Unit Link di Indonesia. 3 Eksyar, 5(1), 28-39.

Sidik, S. (2020). PKPU Kresna Life Dikabulkan, Nasabah Sedih, Bahkan Depresi... CNBC Indonesia.

https://www.cnbcindonesia.com/market/202012 17163423-17-209859/pkpu-kresna-lifedikabulkan-nasabah-sedih-bahkan-depresi

Sudarso, L. (2018). Taktik Berinvestasi Reksa Dana. PT. Elex Media Komputindo. 